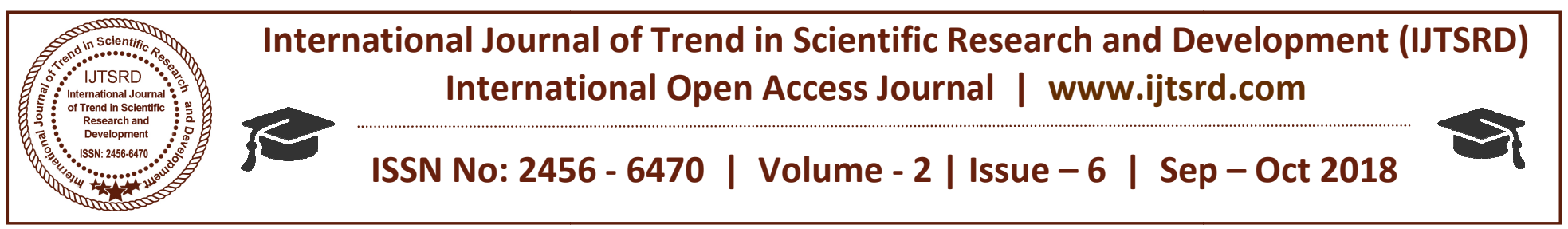

\title{
Revolutionary Change of English Studies in India
}

\author{
S. Joseph Arokia Raj \\ Lecturer (Senior Grade), Shankar Polytechnic College, Tirunelveli, Tamil Nadu, India
}

\begin{abstract}
English is a progressive study motivated by the intellectuals for the development of the national cultivation. English has then started its role in the educational field also. It enlarged its place in range of languages. It is not confined to writing only but it has extended its margin from writing to vocal ornamentation, from a particular definition of a particular thing to wide range of its variety in meaning, from a limited boundary to a no boundary area, from a prevailing cultural identity to a multiple of cultural uniqueness.
\end{abstract}

\section{Keywords: Discipline, Language, Literature}

\section{RESEARCH}

The study of English and its wide spread globalization is a very thrilling topic to discuss about. Though its foot print was seen late at nineteen century yet it was a start up of a vast revolutionary change and the revolution was brought about by the Colonialism and globalization for some historical and political factors. Before we look into the status of English studies in India, let us have a glimpse of the growth of English studies as a discipline in its origin country. Joe Moran (2001) states are certain branch knowledge. The main purpose of universities was to lay open the full body of education and illustrated equally the values and the grounds of all knowledge. The behavior of the university as a closed institution contributed to the association of the disciplines. The development of a new academic issue always subjects to partially on internal influences; top universities identifying it through the formation of separate sections, adequate students and lecturers being engaged to education and impart it, learned societies and journals establishing universally it and known career constructions increasing, generally based on the achievement of a $\mathrm{PhD}$ in that matter. Henceforth, it is significant to reminder that English as a non-specialized subject and its purpose of learning is open in a way even outside the academic set up. As far as literature is concerned, it is about life in all its multiplicity and this is tough to provide accommodations within the selected limitations of a discipline. In the meantime, Raymond Williams takes out the unique sense of literature, which has been dominant to the construction of English as a discipline. Till the closing of the18th century it was in a boundary of all styles of writing, historical, scientific, autobiographical, as well as fictional and cultural. The idea of literature as a focused, extremely appreciated type of writing which was in agreement with the creative or imaginative and different from the genuine or concrete is mostly as developmental form of the post-romantic era. Brian Doyle (1989) says that the growth of English is a progression made by the social more than intellectuals, with the discipline being upheld as exclusively appropriate towards the operation of national growth. He views the formation of educational English as a portion of an extensive social effort merging between the 1880s and the 1920s, known with the measures taken such as the Periodical of the Newbolt Report and the establishment of the English Association which requires renovating cultural Governance by spreading a sense of traditional, cultural and national egotism. Again, Brian Doyle's investigated the growth of English studies in the higher systems of education which is defined as the consequence of national development of Institutionalization. Chris Baldick's(1983) also emphases on the famous critics Leavises, Eliot, Arnold, and Richards, and their effort to claim a broader application for English. He Claims that academic institutionalization of literary education was protected by three issues: the necessities of the British Kingdom, the actions for grownup education and the necessity to style exact provision for the education of women. These features guarantees legendary study, in certain English literature, a everlasting place in advanced education and molded the philosophy and 
practice of English education. A J Palmer (1965) declares that New Universities like King's, Nottingham and Manchester put focus on the study of literature as a representative for social task much earlier the subject was known into Program of study at Oxford and Cambridge. Then John Churton Collins directed a campaign to have English literature as an educational subject at Oxford. He suggested that literature Should be in the enter university syllabuses, it had to do so on the same grounds as other freshly professionalized disciplines, it had to determine that it was marked by objective, techniques of examination and a concern for growth of Knowledge for its own sake, possess a known Construction that would draw the student's improvement from Learner to knowledgeable through a series of lessons, Examinations and certifications. According to Leavis, students of English are basically learning what reading is and what understanding is. Similarly, Hayden White (1977) emphasized that Modern literary critics spot no disciplinary obstacles, both to subject matter or to techniques. Additionally, The Newbolt report of 1921 sets up English literature as the principal foundation of national values; claims that it should take the place of classics as the dominant Humane discipline and even states about the anticipation that it will accept the place of faith in a mostly irreligious culture. At the same time, F R Leavis proposes that English should be moved as essential subject establishing a focus of attraction and fact of liaison for all disciplines within the university. Leavis was involved in a fight to associate the novel governance of English in connection to classics and philosophy. Leavis appreciates the discipline of literary study as the Protection of this marginal culture. He witnesses that the literary critics' task is to mark a type of planned flight from culture in the demand of forming an academic discipline which will finally attain an interdisciplinary Synthesis and a renovation of culture. So Leave's' $\mathrm{PhD}$ dissertation on the connection of journalism and literature turn out to be the establishment of traditional studies. Placing cultural studies experiments the disciplinary Uniqueness of literary studies by liquefying the collection of literature into the more wide-ranging idea of culture. Robert Eaglet one (2000) declares that English is a system which is interconnects and combine together eventually and universe and society by positive values of rationality. But also said that it is a system which is open, continuously in the creation, at no time shut and never to conclude.

\section{English Studies in India:}

English-education is governing the India for more than a century. The starting point of English studies in India can be interrelated to the Well-known Macaulay's Minute. Macaulay's Minute on Education in 1835 , a zone in which description has been given for the offer of encouraging English education in India at the cost of Arabic, Sanskrit, and Persian which were being imparted in the mind at colonial institutes. It acknowledged that it was essential and conceivable to make communities of this nation; Lord Bentinck declared that the main object of the British government must be to promote the European literature and science among the Communities of India and all resources taken for the determination of education would be best hired on English education only. Owing to this preliminary administrative provision, 'English' in India has engaged a noticeable place both in terms of language and as a discipline. As N. Krishnaswamy(2006) says that "The story of English is fascinating story of power and resistance, of invasion and absorption, and of authority and subversion; it is absorbing as any historical novel" (v). In India, we have seena number of problems associated to English as form of education at all heights; Difficulties associated with linguistic nationalism, English being seen as portion of superior and multicultural uniqueness. Again, C D Narasimhaiah (1993) states that the need of India and other earlier colonies of Great Britain as free nations coincided with the end of British impact on English studies exterior to England. In India announcement of National and cultural uniqueness behind and sensed the need to give a touch of their own. So Indian professors initiated in talking about the native authors and they permeated English departments and turn out to be reputable in the eyes of teachers and students. Students started to Claim that an Indian novel be given under common English in place of an English novel. Indian writers established favors with research scholars. And finally Indian Universities gave their response to Indian writing earlier than American universities did to their own literature. In seventies Commonwealth literature held attention of research scholars. And thus, as a result relative approaches towards criticism became unavoidable. The Indian student exposed the advantage of working in a multicultural and vastly pleasing milieu. Meenakshi Mukherjee (1993) declares that continuous construction of post-colonial India continues to be conditioned by the unique instinct that expressed English studies in British India. Even now a hidden 
academic hierarchy that places literature in English overhead the literature of any Indian language. It is critical to identify that, India is one of the most important countries in the world as far as the development of English Studies is concerned. The significance of educating English to traditionally varied groups; syllabus design discussions, some of which claims for educating English for employment, etc. These subjects, particularly enquiries concerning English Studies, have been examined by numerous scholars and now we can assume an evaluation of certain important discussions on English Studies. Some of the recorded vital studies in this style are by Rajeshwari Sunder Rajan (1992); Swathi Joshi (1991); Gauri Vishwanathan (1989); Sudhakar Marathe et al. (1993); Sara Suleri (1992); and Susie Tharu (1997). One of the chief works is that of Gauri Viswanathan's (1989) Masks of Conquest: Literary Study and British Rule in India which claims that the literary syllabus was presented in India not to establish the dominance of English values but to "mask" the economic misuse of the occupied India. The writer says that the literary text performed as a copy of the model Englishman and transformed a mask of misuse that disguised the physical actions of the settling British government. It highlights the point that National commands through language and literature facilities the approach to defeat by power. Sudhakar Mara the et al edited (1993) Provocations: The Teaching of English Literature in India debates the relevance of the study of English literature in postcolonial Indian context. The book reflects on the cultural belongings that English literature carries to Indian mind. The book explores the requirement of indianization of English subdivisions. Rajeshwari Sunder Rajan's (1992) edited work, The Lie of the Land: English Literary Studies in India, also queries the significance and rationality, social purposes, institutional backgrounds, educational and broadcasting practices of English studies in India. This book Pursues to display of traditional orthodoxies, bureaucratic power structures, fossilized thought Processes, un academic institutions, colonial worldviews, outdated theoretical framework which normally describe what it worth to education and teach English literature in India.

\section{Research in English Studies in the Universities of India:}

Ravindra B. Tahsildar (2004) in his review of 'Research Trends in English Studies in Indian Universities', observes that British literature appreciates the Honor place in Indian Universities till now. English an education in India is more than 190 years old and has been a Matter of argument in the previous era of the twentieth century through sessions and conferences. These Debates focused on educating postgraduate divisions in English in recognized Institutions in Indian Universities. English linguistics is presented in some universities owing to the Commendations of numerous groups. With Globalization, spoken English, communication for business, English language teaching, and English for specific revolutionary changes are introduced. With enlarged enrollment of girl students to post graduate programs, women's writing and gender educations are presented. However translation Educations and Aesthetics are ignored part. Some universities have presented research associated papers like, research writing approaches and writing for educational and Professional purposes. These presentation interrelated papers have reached the height of literary studies. Till now, we had a summary of the discipline of English Studies in India. It is clear that study in English Studies is comparatively a current occurrence. Now, the number of doctoral scholars is being greater than before and doctoral education is coming out as a real influence in advanced education. Indian writings in English translation also gained the attention of the research scholars. Comparison of English works with vernacular works became very common ground of attention among research scholars in English studies.

\section{CONCLUSION}

Observation displays that there is serious move in research and curiosity from literature study to Language study. English language education and learning turn out to be the new zone of concentration for research scholars, the students, and professors in the area of English studies. It encouraged research in English language and it also emergence English language labs and training centers. These are certain of the developing movements in English studies in India.

\section{REFERENCES}

1. Baldik, Chris. 1983. The Social Mission of English Criticism: 1848-1932. New York: Oxford University Press.

2. Belsey, Catherine.2007. "Textual Analysis as a Research Method". Griffin, Gabriele. (Ed). Research Methods for English Studies. New Delhi: Raw at Publications. 157-174. 
3. Chandran, Narayana K. 2006. "On English from India: Prepositions to Post-Positions". The Cambridge Quarterly. Vol. 35, No.2: 151-168.

4. Doyle, Brian. 1989. English and Englishness. New York: Rout ledge.

5. Eagleton, Terry. 1996. Literary Theory: An Introduction, Oxford: Blackwell, 2nd edn.

6. Eaglet one, Robert. 2000. Doing English: A Guide for Literature Students. New York: Rout ledge.

7. Fish, Stanley. 1994. "Being Interdisciplinary is So Very Hard to do". There is No Such as Free Speech, and it's a Good Thing, Too. New York: Oxford University Press. 231-42.

8. -----. 1995. Professional Correctness: Literary Studies and Political Change. Cambridge, MA: MIT Press.

9. -----. 1996. "Then We Burn: Violence and Conviction in the English Department". English as Discipline: Or, Is There a Plot in This Play? 160-73.

10. Foucault, Michel.1970. The Order of Things: Archaeology of the Human Sciences. London: Stovistock.

11. ----. 1972. The Archaeology of Knowledge. Trans. A.M. Sheidan Smith. London: Stovistock.

12. Ganguly, S. R. and L. S. Ramaiah. 2000. English Language and Literature Teaching in India: A Bibliography. New Delhi: Munshiram Monoharlal Publishers.

13. Gokak, V. K. 1964. English in India: It's present and Future. Bombay: Asia Publishing House.

14. Gowda, H. H. Anniah. 1978. Research in English: Language and Literature; Language or Literature. In Ramesh Mohan (ed.) Indian Writing in English. Madras: Orient Longman.

15. Griffin, Gabriele.(Ed). 2005. Research Methods for English Studies. New Delhi: Rawat Publications.
16. Joshi, Swathi. (Ed). 1994. Rethinking English in India. Bombay: Oxford University Press.

17. Krishnaswamy, N and Krishnaswamy, Lalitha.2006. The Story of English in India. New Delhi: Foundation Books.

18. Kushawa, M.S. and Kamal Naseem. 2000. Indian Doctoral Dissertations in English Studies: A Reference Guide. New Delhi: Atlantic Publishers and Distributers.

19. Leavis, F. R. 1948. Education and the University: A Sketch for an "English School", London: Chatto and Wind us, 2nd edn.

20. Marathe, Sudhakar, et al. eds. 1993. Provocations: The Teaching of English Literature in India. Chennai: Orient Black swan.

21. McCrum, R. W. Cran and R. MacNeil. 1986. The Story of English. New York: Viking Penguin.

22. Moran, Joe. 2007. Interdisciplinarity. London: Rout ledge.

23. Mukherji, Meenakshi. 1993. "Certain LongSimmering Questions", Sudhakar Marathe, (eds.) Provocations: The Teaching of English Literature in India. Chennai: Orient Blacks wan

24. Narasimhaiah, C.D. 1993. "Retrospect and Prospect", Sudhakar Mara the, (eds.) Provocations: The Teaching of English Literature in India Chennai: Orient Blackswan.

25. Pope, Rob. 1998. Studying English Literature and Language: An Introduction and Companion. New York: Rout ledge.

26. Palmer, D J. 1965. The Rise of English Studies: An account of the study of English literature from its Origins to the making of the Oxford English School, London: Oxford University Press.

27. Sastry Krishna L S R. 1993. "Objectives and Meaningfulness of Research". Sudhakar Mara the, Mohan Ramanan and Robert Bella mine (Eds.), Provocations. Madras: Orient Longman Ltd. 6775. 